\title{
Analisis Prediksi Masa Manfaat PLTD PT PLN (Persero) Kabupaten Kepulauan Selayar dengan Metode Regresi
}

\author{
Abdul Malikil Mulki ${ }^{1}$, Suryanto ${ }^{2}$, Remigius Tandioga ${ }^{3}$ \\ 1,2,3 Jurusan Teknik Mesin, Politeknik Negeri Ujung Pandang, Makassar 90245, Indonesia \\ suryanto@poliupg.ac.id
}

\begin{abstract}
Abstrak- Dalam penelitian ini diditeliti suatu metode untuk memprediksi masa pakai suatu pembangkit menggunakan prinsip matematis dengan data aktual dari tahun 2013 sampai dengan 2017 yaitu data pemasukan (benefit) yang terdiri dari pemasukan dari penjualan listrik dan subsidi dan biaya (cost) yang terdiri dari bahan bakar, pemeliharaan, gaji pegawai, penyusutan, dan administrasi setiap tahun yang dimodelkan dalam bentuk matriks untuk mendapatkan koefisien-koefisien persamaan regresi kuadratis dengan menganggap tahun sebagai variabel bebas, sedangkan variabel tidak bebas adalah benefitdancost. Hasil regresi benefit dan cost dicari korelasi kedekatan kecocokan data aktual dengan hasil regresi dalam persentase, kemudian dicari titk temu dari hasil regresi benefit dan cost, jika nilai benefit sama dengan nilai cost maka secara finansial tidak menguntungkan, dan tidak merugikan (breaking point), Hasil penelitian menunjukkan bahwa masa pakai keempat unit mesin PLTD Selayar tercapai pada titik pertemuan antara kurva benefit dan kurva cost rata-rata berada pada tahun 2016 dengan masa pakai umur pembangkit 29 tahun mulai dioperasikan sejak tahun 1987, secara teknis mesin tersebut masih bisa dioperasikan setelah tahun 2016 namun secara finansial tidak menguntungkan lagi.
\end{abstract}

Kata kunci: regresi, masa manfaat, breaking point

\section{PENDAhUluan}

Seiring pertumbuhan ekonomi di Indonesia kebutuhan listrik saat ini terus meningkat. Meningkatnya kebutuhan listrik ini disebabkan karena adanya penggunaan listrik yang berlebihan dalam kehidupan sehari-hari baik itu di rumah tangga maupun di industri. Agar keterbatasan energi listrik ini tidak berkelanjutan maka didirikanlah pembangkitpembangkit listrik yang bisa memasok kebutuhan listrik di sejumlah daerah terpencil di indonesia.

PLTD Pulau Selayar memiliki 10 unit set mesin dengan merek dan kapasitas berbeda. Empat unit mesin dengan merek Deutz type BV 8M 628 mulai beroperasi pada tahun 1987 dan memiliki daya terpasang masing-masing $1200 \mathrm{~kW}$ tiap unit, dan dua mesin merekMTU dan SWD dengan kapasitas masing-masing $1200 \mathrm{~kW}$ dioperasikan pada tahun 2004 dan 1977 dan saat ini kedua pembangkit tersebut sudah tidak beroperasi. Pada tahun 2017 ada penambahan pembangkit empat unit dengan merek Altrak masing - masing berkapasitas $1000 \mathrm{~kW}$ yang mulai beroperasi pada tahun 2017. Total daya terpasang yang dapat melayani kebutuhan listrik masyarakatPulau Selayar adalah 8800 kW. Dari kesepuluh unit tersebut empat di antaranya yaitu merek Deutz type BV 8M 628 secara ekonomis perlu dipertimbangkan atau diprediksi umur pakainya, karena umur pakai akan dapat

Submitted: 30/04/2020; Revised: 23/05/2020; mempengaruhi performance pembangkit. Selain faktor teknis, faktor ekonomi juga merupakan faktor terpenting yang perlu diperhitungkan.

Dalam penelitian ini penulis akan menawarkan suatu metode untuk memprediksi masa pakai suatu pembangkit menggunakan prinsip matematis metode kuadrat terkecil (methode of least squares) yang dikembangkan oleh [1]. Dalam penelitian ini penulis menggunakan dua buah data aktual dari tahun 2013 sampai dengan 2017 yaitu data biaya pemasukan (Benefit) yang terdiri dari biaya harga jual listrik dan subsidi pemerintah dan biaya pengeluaran (Cost) yang terdiri dari biaya bahan bakar, pemeliharaan, gaji pegawai, penyusutan, dan administrasi setiap tahun. Penulis mengacu pada penelitian yang telah dilakukan [2] dengan judul Metode Regresi Linear, untuk memprediksi kebutuhan Energi listrik jangka panjang. Demikian juga [3] dalam studi kelayakan penggunaan mesin diesel dengan metode Break Even Point, dan didukung berbagai jurnal internasional IEEE di antaranya [4] dengan judul Solar Power Probabilistic Forecasting by Using Multiple Linear Regresssion Analysis. Demikian juga [5] dengan judul Fault prediction for power plant equipment based on support vector regresssion dan [6] Thermal performance of natural draft wet cooling towers under cross-wind conditionsn based on experimental data and regression analysis.

Berdasarkan uraian diatas penulis tertarik untuk menganalisa prediksi masa pakaisuatu mesin PLTD terhadap biaya benefit dan cost pada PT PLN (Persero) Kabupaten Kepulauan Salayar dengan menggunakan metode regresi. Prediksi dilakukan dengan mengambil kedua data aktual tersebut, dimana nilai aktual benefit akan menurun setiap tahun sedangkan nilai cost mengalami kenaikan. Dengan memanfaatkan nilai yang bertolak belakang kemudian diregresi dengan tahun berjalan sampai beberapa tahun mendatang. Jika nilaibenefitsama dengan nilai cost maka secara finansial tidak menguntungkan, dan tidak merugikan (breaking point) Dapat dikatakan bahwa prediksi masa pakai sudah tercapai pada titik pertemuan antara kurva benefit dan kurva cost

\section{Metode Penelitian}

Lokasi penelitian dilakukan di PLTD PT PLN (Persero) KabupatenKepulauanSalayar untuk unit I, II, III, dan IV. Data aktual benefit dibutuhkan untuk melakukan perhitungan, terdiri dari harga jual listrik per $\mathrm{kWh}$ dan subsidi per $\mathrm{kWh}$ setiap tahun dan cost yang terdiri dari biaya bahan bakar, 
biaya pemeliharaan, gaji pegawai, penyusutan, dan Administrasi

\section{A. Teknik Analisa Data.}

Data ini diperoleh dari dokumentasi beberapa tahun. Dalam analisa ini digunakan 5 tahun karena keterbatasan data dokumentasi dari PT PLN (PERSERO).

1. Pemodelan dengan matriks untuk mendapatkan koefisien-koefisien $\alpha, \quad \beta$, dan $\gamma$ regresi dengan menggunakan kedua data aktual yaitu data benefit dan cost.

2. Membuat persamaan regresi kuadratis $\hat{y}=\alpha+\beta \cdot x+\gamma \cdot x^{2}$ nilai aktual benefit dan cost dengan mengambil nilai koefisien.

3. Meregresikan dengan menggunakan persamaan kuadratis dengan menganggap tahun sebagai variabel bebas, sedangkan variabel tak bebas adalah benefit dan cost.

4. Membuat pemodelan korelasi $R^{2}=(\hat{y}-\bar{y})^{2} /(y-\bar{y})^{2}$ digunakan sebagai alat bantu dalam regresi untuk mencari hubungan terhadap variabel bebas dan variabel tak bebas dalam persentase.

5. Menentukan prediksi masa pakai mesin secara finansial dengn mencari titik pertemuan antara kurva hasil regresi benefit dan hasil regresi cost.

6. Membuat kesimpulan dari hasil regresi benefit, cost, dan korelasi variabel bebas dan tak bebas

\section{HASIL DAN PEMBAHASAN}

Pusat Listrik Tenaga Diesel (PLTD) Selayar berada di Jalan Poros Lembang Mate'ne Desa Parak Kecamatan Bontomanai, Kabupaten Kepulauan Selayar saat ini memiliki kapasitas sekitar $6 \mathrm{MW}$, dan akan dilakukan penambahan kapasitas menjadi 10 MW. Peningkatan kapasitas dilakukan dengan pengadaan 4 unit mesin PLTD dengan kapasitas 4 MW, yang dilakukan secara bertahap, untuk tahap pertama adalah pengadaan 2 unit mesin, dan selanjutnya juga 2 unit mesin [7].

TABEL 1

DATA PERALATAN MESIN PLTD SELAYAR [7]

\begin{tabular}{|c|l|c|c|c|c|}
\hline No & Merek & $\begin{array}{c}\text { Jenis } \\
\text { Pembangkit }\end{array}$ & $\begin{array}{c}\text { Tahun } \\
\text { Operasi }\end{array}$ & Kapasitas & Kondisi \\
\hline A & Eksisting & & & & \\
\hline 1 & Deutz I & Diesel & 1987 & $1,2 \mathrm{MW}$ & Operasi \\
\hline 2 & Deutz II & Diesel & 1987 & $1,2 \mathrm{MW}$ & Operasi \\
\hline 3 & Deutz III & Diesel & 1987 & $1,2 \mathrm{MW}$ & Operasi \\
\hline 4 & Deutz IV & Diesel & 1987 & $1,2 \mathrm{MW}$ & Operasi \\
\hline 5 & MTU & Diesel & 2004 & $1,2 \mathrm{MW}$ & Perbaikan \\
\hline 6 & SWD & Diesel & 1977 & - & Perbaikan \\
\hline B & Penambahan & & & & \\
\hline 1 & Altrak & Diesel & 2017 & $1 \mathrm{MW}$ & Baik \\
\hline 2 & Altrak & Diesel & 2017 & $1 \mathrm{MW}$ & Baik \\
\hline 3 & Altrak & Diesel & 2017 & $1 \mathrm{MW}$ & Baik \\
\hline 4 & Altrak & Diesel & 2017 & $1 \mathrm{MW}$ & Baik \\
\hline
\end{tabular}

\section{A. Perhitungan Biaya Penggunaan Mesin Diesel pada PLTD Selayar}

Biaya dalam penggunaan mesin diesel untuk memenuhi kebutuhan listrik masyarakat Kepulauan Selayar terdiri dari biaya fix cost dan Variabel cost. Dalam skripsi ini yang termasuk fix cost adalah biaya penyusutan mesin dan biaya gaji karyawan, Sedangkan untuk biaya variabel cost terdiri dari biaya operasional pemakaian bahan bakar, administrasi, dan pemeliharaan. Adapun biaya variabel cost dan fix cost dalam analisa ini diambil dari data tahun 2013 sampai dengan tahun 2017

TABEL 2

HASIL AKUMULASI DATA BIAYA TAHUNAN PERIODE 2013-2017 MESIN DEUTZ I

\begin{tabular}{|c|l|c|c|c|c|c|}
\hline \multirow{2}{*}{ No } & \multirow{2}{*}{ Biaya } & \multicolumn{5}{|c|}{ PLTD Selayar Deutz I (Miliar Rupiah) } \\
\cline { 3 - 7 } & & $\mathbf{2 0 1 3}$ & $\mathbf{2 0 1 4}$ & $\mathbf{2 0 1 5}$ & $\mathbf{2 0 1 6}$ & $\mathbf{2 0 1 7}$ \\
\hline 1 & $\begin{array}{l}\text { Biaya Bahan } \\
\text { Bakar }\end{array}$ & 12,093 & 14,282 & 8,640 & 10,302 & 6,047 \\
\hline 2 & $\begin{array}{l}\text { Biaya } \\
\text { Pemeliharaan }\end{array}$ & 1,217 & 0,580 & 0,644 & 2,182 & 0,949 \\
\hline 3 & Gaji Pegawai & 0,117 & 0,250 & 0,340 & 0,367 & 0,468 \\
\hline 4 & Penyusutan & 0,320 & 0,565 & 0,621 & 2,044 & 2,084 \\
\hline 5 & Administrasi & 0,026 & 0,030 & 0,027 & 0,039 & 0,040 \\
\hline & Total & $\mathbf{1 3 , 7 7 3}$ & $\mathbf{1 5 , 7 0 7}$ & $\mathbf{1 0 , 2 7 2}$ & $\mathbf{1 4 , 9 3 4}$ & $\mathbf{9 , 5 9 0}$ \\
\hline
\end{tabular}

TABEL 3

HASIL AKUMULASI DATA BIAYA TAHUNAN PERIODE 2013-2017 MESIN DEUTZ II

\begin{tabular}{|c|l|c|c|c|c|c|}
\hline \multirow{2}{*}{$\mathbf{0}$} & \multirow{2}{*}{ Biaya } & \multicolumn{4}{|c|}{ PLTD Selayar Deutz II (Miliar Rupiah) } \\
\cline { 3 - 7 } & & $\mathbf{2 0 1 3}$ & $\mathbf{2 0 1 4}$ & $\mathbf{2 0 1 5}$ & $\mathbf{2 0 1 6}$ & $\mathbf{2 0 1 7}$ \\
\hline 1 & Biaya Bahan Bakar & 12,328 & 11,805 & 9,519 & 5,603 & 6,403 \\
\hline 2 & Biaya Pemeliharaan & 2,919 & 1,120 & 0,489 & 3,788 & 1,219 \\
\hline 3 & Gaji Pegawai & 0,117 & 0,250 & 0,340 & 0,367 & 0,468 \\
\hline 4 & Penyusutan & 0,111 & 0,146 & 0,148 & 0,381 & 0,379 \\
\hline 5 & Administrasi & 0,026 & 0,030 & 0,027 & 0,039 & 0,040 \\
\hline & Total & $\mathbf{1 5 , 5 0 0}$ & $\mathbf{1 3 , 3 5 2}$ & $\mathbf{1 0 , 5 2 1}$ & $\mathbf{1 0 , 1 7 8}$ & $\mathbf{8 , 5 0 8}$ \\
\hline
\end{tabular}

TABEL 4

HASIL AKUMULASI DATA BIAYA TAHUNAN PERIODE 2013-2017 MESIN DEUTZ III

\begin{tabular}{|c|l|c|c|c|c|c|}
\hline \multirow{2}{*}{ No } & \multirow{2}{*}{ Biaya } & \multicolumn{3}{|c|}{ PLTD Selayar Deutz III } & \multicolumn{3}{c|}{ (Miliar Rupiah) } \\
\cline { 3 - 7 } & & $\mathbf{2 0 1 3}$ & $\mathbf{2 0 1 4}$ & $\mathbf{2 0 1 5}$ & $\mathbf{2 0 1 6}$ & $\mathbf{2 0 1 7}$ \\
\hline 1 & Biaya Bahan Bakar & 11,713 & 11,951 & 9,856 & 7,872 & 4,922 \\
\hline 2 & Biaya Pemeliharaan & 0,252 & 1,120 & 0,489 & 3,788 & 1,219 \\
\hline 3 & Gaji Pegawai & 0,117 & 0,250 & 0,340 & 0,367 & 0,468 \\
\hline 4 & Penyusutan & 0 & 0,000 & 0,000 & 0,544 & 0,568 \\
\hline 5 & Administrasi & 0,026 & 0,030 & 0,027 & 0,039 & 0,040 \\
\hline \multicolumn{2}{c}{ Total } & $\mathbf{1 2 , 1 0 7}$ & $\mathbf{1 3 , 3 5 2}$ & $\mathbf{1 0 , 7 1 1}$ & $\mathbf{1 2 , 6 1 1}$ & $\mathbf{7 , 2 1 7}$ \\
\hline
\end{tabular}


TABEL 5

HASIL AKUMULASI DATA BIAYA TAHUNAN PERIODE 2013-2017 MESIN DEUTZ IV

\begin{tabular}{|c|l|c|c|c|c|c|}
\hline \multirow{2}{*}{ No } & \multirow{2}{*}{ Biaya } & \multicolumn{5}{|c|}{ PLTD Selayar Deutz IV (Miliar Rupiah) } \\
\cline { 3 - 7 } & & $\mathbf{2 0 1 3}$ & $\mathbf{2 0 1 4}$ & $\mathbf{2 0 1 5}$ & $\mathbf{2 0 1 6}$ & $\mathbf{2 0 1 7}$ \\
\hline 1 & Biaya Bahan Bakar & 12,587 & 8,703 & 10,193 & 5,827 & 6,441 \\
\hline 2 & Biaya Pemeliharaan & 1,161 & 0,639 & 1,872 & 2,399 & 1,233 \\
\hline 3 & Gaji Pegawai & 0,117 & 0,250 & 0,340 & 0,367 & 0,468 \\
\hline 4 & Penyusutan & 0,065 & 0,086 & 0,087 & 0,225 & 0,266 \\
\hline 5 & Administrasi & 0,026 & 0,030 & 0,027 & 0,039 & 0,040 \\
\hline \multicolumn{2}{|c|}{ Total } & $\mathbf{1 3 , 9 5 5}$ & $\mathbf{9 , 7 0 9}$ & $\mathbf{1 2 , 5 1 9}$ & $\mathbf{8 , 8 5 6}$ & $\mathbf{8 , 4 4 9}$ \\
\hline
\end{tabular}

TABEL 6

HASIL AKUMULASI PRODUKSI LISTRIK NETTO TAHUNAN PERIODE 2013-2017 MESIN DEUTZ I, II,III DAN IV

\begin{tabular}{|c|c|c|c|c|c|}
\hline \multirow{2}{*}{ Mesin } & \multicolumn{5}{|c|}{ Produksi Listrik Netto (kWh) } \\
\cline { 2 - 6 } & $\mathbf{2 0 1 3}$ & $\mathbf{2 0 1 4}$ & $\mathbf{2 0 1 5}$ & $\mathbf{2 0 1 6}$ & $\mathbf{2 0 1 7}$ \\
\hline Deutz I & 4.146 .994 & 4.228 .006 & 3.666 .164 & 4.341 .741 & 1.425 .396 \\
\hline Deutz II & 4.561 .382 & 3.976 .396 & 4.383 .719 & 3.935 .909 & 1.491 .577 \\
\hline Deutz III & 4.317 .745 & 3.994 .646 & 4.686 .656 & 5.145 .335 & 1.119 .313 \\
\hline $\begin{array}{c}\text { Deutz } \\
\text { IV }\end{array}$ & $\begin{array}{c}4.646 .64 \\
8\end{array}$ & $\begin{array}{c}2.914 .25 \\
1\end{array}$ & $\begin{array}{c}4.500 .64 \\
7\end{array}$ & $\begin{array}{c}3.703 .97 \\
4\end{array}$ & $\begin{array}{c}1.364 .98 \\
7\end{array}$ \\
\hline
\end{tabular}

B. Analisis Manfaat Penggunaan Mesin Diesel pada PLTD Selayar

Tujuan utama dari perancangan dan operasi suatu sistem pembangkit listrik adalah untuk memperoleh biaya produksi energi listrik seminimum mungkin namun pada pembangkit terkadang biaya produksi lebih besar dari pada harga jual hal ini disebabkan karena adanya faktor politik dan sosial ekonomi sehingga kebijakan mempengaruhi harga jual, sehingga dibutuhkan subsidi agar pembangkit tersebut masih bisa beroperasi. Maka dalam hal ini pemerintah mensubsidi dua kategori konsumen, yakni $450 \mathrm{VA}$, dan 900VA. Untuk konsumen 450 VA meningkat dari 15,5 juta pelanggan menjadi sekitar 23 juta konsumen (Kompas.com 14/6/2017) sehingga mesin yang beroperasi secara ekonomi tidak layak lagi namun masih dipertahankan karena adanya subsidi sekitar Rp.3500/kWh. Jika dibandingkan harga jual listrik tanpa subsidi seperti pada pulau terluar (Masalembu) tarif listrik sejak dikelola oleh suadaya masyarakat harga jual sebesar Rp.5400/kWh. Namun saat ini dikelola oleh Koperlindo menjadi Rp.4250/kWh menurut (Sumber Sumenep, Info Publik) [8].

Dalam Peraturan Menteri Energi dan Sumber Daya Mineral Republik Indonesia Nomor 31 tahun 2014 tentang tarif tenaga listrik yang disediakan oleh Perusahaan Perseroan (Persero) PT Perusaaan Listrik Negara terdiri dari empat macam tarif listrik yaitu Tarif listrik rumah tangga, keperluan sosial bisnis dan industri. Dalam laporan skripsi ini diambil dasar golongan tarif S-2/TR dengan batas daya $900 \mathrm{VA}$ dan biaya pemakaian per kWh untuk blok I pemakaian 20 sampai dengan $60 \mathrm{kWh}$ harga jual Rp.200/kWh, untuk blok II pemakaian 0 sampai dengan $20 \mathrm{kWh}$ harga jual Rp.295/kWh, untuk blok III pemakaian diatas $60 \mathrm{kWh}$ harga jual Rp.360/kWh, dan prabayar Rp.455/kWh. Blok I pemakaian 0 sampai dengan $108 \mathrm{kWh}$ dengan harga jual Rp.420/kWh, untuk blok II diatas $108 \mathrm{kWh}$ dengan harga jual Rp.465/kWh, dan untuk prabayar harga jual Rp.630/kWh. Berdasarkan data harga jual listrik dan subsidi tersebut maka dalam penelitian ini diambil dasar seperti pada Tabel 7.

TABEL 7

HARGA JUAL LISTRIK TAHUNAN DAN SUBSIDI PEMERINTAH TAHUN 2013 SAMPAI DENGAN 2017

\begin{tabular}{|c|c|c|c|c|c|}
\hline \multirow{2}{*}{ Tahun } & \multicolumn{5}{|c|}{ Harga Listrik Tahunan (Rp./kWh) } \\
\cline { 2 - 6 } & $\mathbf{2 0 1 3}$ & $\mathbf{2 0 1 4}$ & $\mathbf{2 0 1 5}$ & $\mathbf{2 0 1 6}$ & $\mathbf{2 0 1 7}$ \\
\hline Harga Jual Listrik (Rp./kWh) & 455 & 500 & 550 & 600 & 650 \\
\hline Subsidi (Rp./kWh) & 3.500 & 3.500 & 3.500 & 3.500 & 3.500 \\
\hline Total & 3.955 & 4.000 & 4.050 & 4.100 & 4.150 \\
\hline
\end{tabular}

Harga listrik tahunan dan Produksi listrik Netto untuk mesin benefit Deutz I sampai dengan Deutz IV diambil kemudian benefit ditentukan dengan mengalikan hasil produksi listrik netto dengan harga jual listrik ditambah subsidi, dari hasil perkalian tersebut diperoleh nilai seperti pada Tabel 8 .

TABEL 8

BENEFIT DARI MESIN DEUTZ I SAMPAI DENGAN DEUTZ IV

\begin{tabular}{|c|c|c|c|c|c|}
\hline \multirow{2}{*}{ Mesin } & \multicolumn{5}{|c|}{ Benefit (Miliar Rupiah) } \\
\cline { 2 - 6 } & $\mathbf{2 0 1 3}$ & $\mathbf{2 0 1 4}$ & $\mathbf{2 0 1 5}$ & $\mathbf{2 0 1 6}$ & $\mathbf{2 0 1 7}$ \\
\hline Deutz I & 16,401 & 16,912 & 14,848 & 17,801 & 5,915 \\
\hline Deutz II & 18,040 & 15,906 & 17,754 & 16,137 & 6,190 \\
\hline Deutz III & 17,077 & 15,979 & 18,981 & 21,096 & 4,645 \\
\hline Deutz IV & 18,377 & 11,657 & 18,228 & 15,186 & 5,665 \\
\hline
\end{tabular}

Perhitungan matriks dilakukan untuk menetukan nilai koefesien data benefit dengan menentukan terlebih dahulu data real benefit dan cost dan jumlah banyaknya data, kemudian meregresikan maka akan didapatkan persamaaan regresinyan kuadratisnya benefit dan cost adala sebagai berikut untuk mesin duetz I, duetz II, duetz III, dan duetz IV Untuk duetz 1 didapatkan persamaan sebagai berikut :

TABEL 9

HASIL AKUMULASI BIAYA BENEFIT PADA MESIN DEUTZ I

\begin{tabular}{|l|c|c|c|c|c|}
\hline \multirow{2}{*}{ Tahun } & \multicolumn{5}{|c|}{ Mesin Deutz I } \\
\cline { 2 - 6 } & $\mathbf{2 0 1 3}$ & $\mathbf{2 0 1 4}$ & $\mathbf{2 0 1 5}$ & $\mathbf{2 0 1 6}$ & $\mathbf{2 0 1 7}$ \\
\hline $\begin{array}{l}\text { Benefit (Miliar } \\
\text { Rupiah) }\end{array}$ & 16,401 & $\begin{array}{c}16,91 \\
2\end{array}$ & $\begin{array}{c}14,84 \\
8\end{array}$ & $\begin{array}{c}17,80 \\
1\end{array}$ & $\begin{array}{c}5,91 \\
5\end{array}$ \\
\hline $\begin{array}{l}\text { Cost (Miliar } \\
\text { Rupiah) }\end{array}$ & 13,773 & $\begin{array}{c}15,70 \\
7\end{array}$ & $\begin{array}{c}10,27 \\
2\end{array}$ & $\begin{array}{c}14,93 \\
4\end{array}$ & $\begin{array}{c}9,59 \\
0\end{array}$ \\
\hline
\end{tabular}




$$
\begin{aligned}
\hat{\mathrm{y}}_{\text {Benefit }} & =10,51263+6,466967 x-1,41254 x^{2} \\
\hat{\mathrm{y}}_{\text {Cost }} & =13,3674+0,9971 x-0,3185 x^{2}
\end{aligned}
$$

Untuk Uji korelasi $\mathrm{R}^{2}$ digunakan untuk melihat kecocokan data real dan hasil regresi dan persentase dengan mengambil data real dan hasil regresi.

Maka korelasi Uji $\mathrm{R}^{2}$ benefit pada mesin Deutz I didapatkan hasil sebagai berikut:

$$
\mathrm{R}^{2}=\frac{\sum_{i=1}^{n}\left(\hat{\mathrm{y}}_{i}-\overline{\mathrm{y}}\right)^{2}}{\sum_{i=1}^{n}\left(\mathrm{Y}_{i}-\overline{\mathrm{y}}\right)^{2}}=\frac{68,253}{94,070}=0,726
$$

Maka korelasi Uji $\mathrm{R}^{2}$ cost pada mesin Deutz 1 didapatkan hasil sebagai berikut :

$$
R^{2}=\frac{\sum_{i=1}^{n}\left(\hat{\mathrm{y}}_{i}-\overline{\mathrm{y}}\right)^{2}}{\sum_{i=1}^{n}\left(\mathrm{Y}_{i}-\overline{\mathrm{y}}\right)^{2}}=\frac{9,8}{30,638}=0,319
$$

TABEL 10

HASIL REGRESI MESIN DEUTZ I

\begin{tabular}{|c|c|c|c|c|c|c|}
\hline \multirow{2}{*}{$\begin{array}{c}\text { Tah } \\
\text { un }\end{array}$} & $\begin{array}{c}\text { Mata } \\
\text { Real } \\
\text { Benefit } \\
\text { (Miliar } \\
\text { Rupiah } \\
\text { ) }\end{array}$ & $\begin{array}{c}\text { Hasil } \\
\text { Regresi } \\
\text { Benefit } \\
\text { Rupiah } \\
\text { Rupiah }\end{array}$ & $\begin{array}{c}\text { Data } \\
\text { Real } \\
\text { Cost } \\
\text { (Miliar } \\
\text { Rupiah } \\
\text { ) }\end{array}$ & $\begin{array}{c}\text { Hasil } \\
\text { Regresi } \\
\text { Cost } \\
\text { (Miliar } \\
\text { Rupiah } \\
\text { ) }\end{array}$ & $\begin{array}{c}\text { Hasil } \\
\text { Regr } \\
\text { esi } \\
\text { (B/C }\end{array}$ & $\begin{array}{c}\text { Hasil } \\
\text { Regresi } \\
\text { (B-C) } \\
\text { (Miliar } \\
\text { Rupiah } \\
\text { ) }\end{array}$ \\
\hline 2013 & 16,401 & 15,568 & 13,773 & 14,046 & 1,108 & 1,522 \\
\hline 2014 & 16,912 & 17,797 & 15,707 & 14,088 & 1,263 & 3,709 \\
\hline 2015 & 14,848 & 17,202 & 10,272 & 13,493 & 1,275 & 3,709 \\
\hline 2016 & $\mathbf{1 7 , 8 0 1}$ & $\mathbf{1 3 , 7 8 1}$ & $\mathbf{1 4 , 9 3 4}$ & $\mathbf{1 2 , 2 6}$ & $\mathbf{1 , 1 2 4}$ & $\mathbf{1 , 5 2 1}$ \\
\hline 2017 & 5,915 & 7,536 & 9,59 & 10,391 & 0,725 & $-2,855$ \\
\hline 2018 & & $-1,535$ & & 7,884 & - & $-9,419$ \\
\hline 2019 & & $-13,431$ & & 4,74 & $\begin{array}{c}- \\
2,834\end{array}$ & $-18,171$ \\
\hline 2020 & & $-28,151$ & & 0,958 & $\begin{array}{c}29,38 \\
5\end{array}$ & $-29,109$ \\
\hline 2021 & & $-45,697$ & & $-3,46$ & $\begin{array}{c}13,20 \\
7\end{array}$ & $-42,237$ \\
\hline 2022 & & $-66,067$ & & $-8,516$ & 7,758 & $-57,551$ \\
\hline & $-89,263$ & & $-14,209$ & 6,282 & $-75,054$ \\
\hline
\end{tabular}

TABEL 11

HASIL AKUMULASI BIAYA COST DAN BENEFIT PADA MESIN DEUTZ II

\begin{tabular}{|l|c|c|c|c|c|}
\hline \multirow{2}{*}{ Tahun } & \multicolumn{5}{|c|}{ Mesin Deutz II } \\
\cline { 2 - 6 } & $\mathbf{2 0 1 3}$ & $\mathbf{2 0 1 4}$ & $\mathbf{2 0 1 5}$ & $\mathbf{2 0 1 6}$ & $\mathbf{2 0 1 7}$ \\
\hline Benefit ( Miliar Rupiah) & 18,040 & 15,906 & 17,754 & 16,137 & 6,190 \\
\hline Cost ( Miliar Rupiah) & 15,390 & 13,206 & 10,374 & 10,341 & 8,697 \\
\hline
\end{tabular}

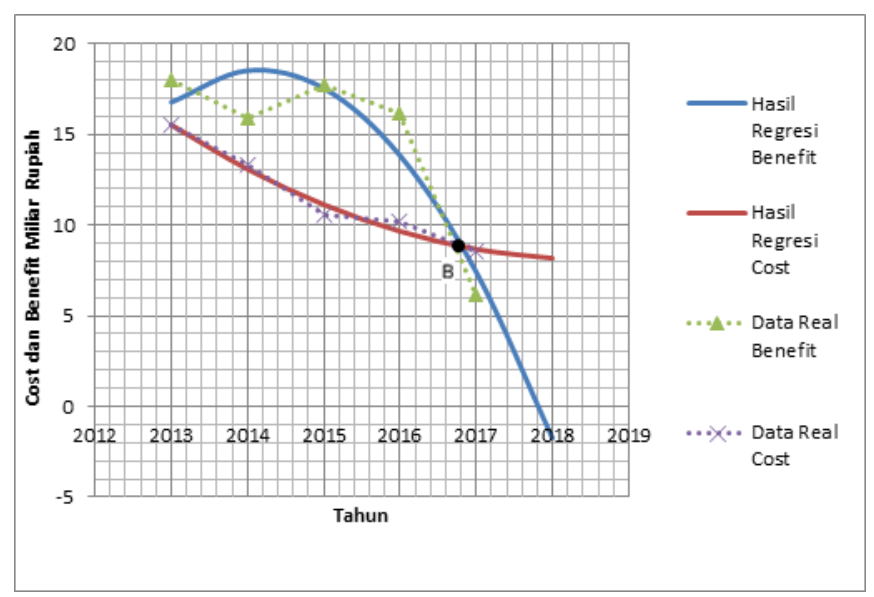

\begin{tabular}{|c|c|c|c|c|c|c|}
\hline Tahun & $\begin{array}{c}\text { Hasil } \\
\text { Regresi } \\
\text { Benefit } \\
\text { (Miliar } \\
\text { Rupiah) }\end{array}$ & $\begin{array}{c}\text { Hasil } \\
\text { Regresi } \\
\text { Cost } \\
\text { (Miliar } \\
\text { Rupiah }\end{array}$ & $\begin{array}{c}\text { Data } \\
\text { Real } \\
\text { Benefit } \\
\text { (Miliar } \\
\text { Rupiah) }\end{array}$ & $\begin{array}{c}\text { Data } \\
\text { Real } \\
\text { Cost } \\
\text { (Miliar } \\
\text { Rupiah) }\end{array}$ & $\mathrm{B} / \mathrm{C}$ & $\begin{array}{c}\text { B-C } \\
\\
\text { (Miliar } \\
\text { Rupiah) }\end{array}$ \\
\hline 2013 & 16,773 & 15,535 & 18,040 & 15,500 & 1,0797 & 1,238 \\
\hline 2014 & 18,516 & 13,076 & 15,906 & 13,352 & 1,416 & 5,44 \\
\hline 2015 & 17,533 & 11,107 & 17,754 & 10,521 & 1,579 & 6,425 \\
\hline 2016 & 13,823 & 9,628 & 16,137 & 10,178 & 1,436 & 4,195 \\
\hline 2017 & 7,385 & 8,637 & 6,190 & 8,508 & 0,855 & $-1,253$ \\
\hline 2018 & $-1,7804$ & 8,136 & & & $-0,219$ & $-9,916$ \\
\hline 2019 & $-13,673$ & 8,123 & & & $-1,683$ & $-21,796$ \\
\hline 2020 & $-28,292$ & 8,600 & & & $-3,29$ & $-36,892$ \\
\hline 2021 & $-45,639$ & 9,567 & & & $-4,771$ & $-55,205$ \\
\hline
\end{tabular}

Gambar 1. Grafik hasil regresi data benefit dan cost pada mesin Deutz I

TABEL 12

HASIL REGRESI MESIN DEUTZ II

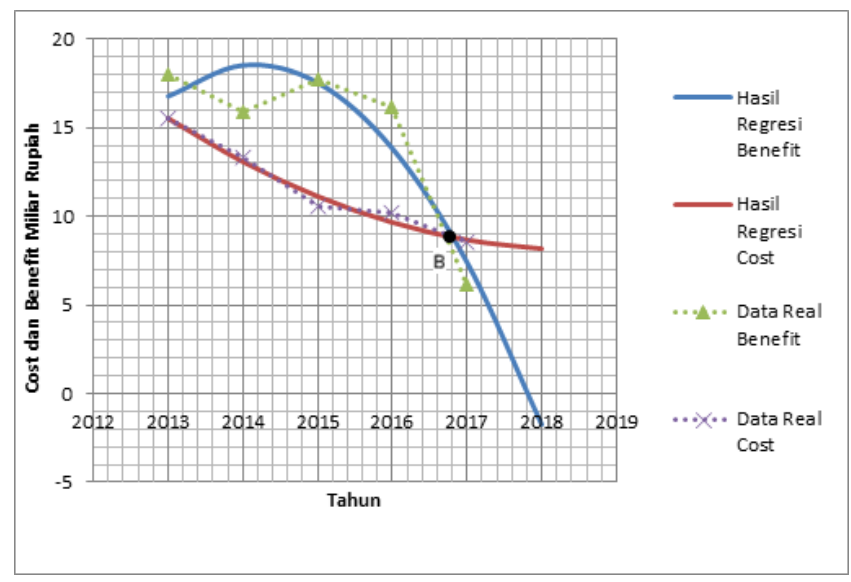

Gambar 2. Grafik hasil regresi data benefit dan cost pada mesin Deutz II 
TABEL 13

HASIL AKUMULASI BIAYA BENEFIT PADA MESIN DEUTZ III

\begin{tabular}{|l|c|c|c|c|c|}
\hline \multirow{2}{*}{ Tahun } & \multicolumn{5}{|c|}{ Mesin Deutz III } \\
\cline { 2 - 6 } & 2013 & 2014 & 2015 & 2016 & 2017 \\
\hline Benefit (Miliar Rupiah) & 17,077 & 15,979 & 18,981 & 21,096 & 4,645 \\
\hline Cost (Miliar Rupiah) & 12,107 & 13,352 & 10,711 & 12,611 & 7,217 \\
\hline
\end{tabular}

TABEL 14

HASIL REGRESI MESIN DEUTZ III

\begin{tabular}{|c|c|c|c|c|c|c|}
\hline $\begin{array}{c}\text { Tah } \\
\text { un }\end{array}$ & $\begin{array}{c}\text { Hasil } \\
\text { Regresi } \\
\text { Benefit } \\
\text { (Miliar } \\
\text { Rupiah } \\
\text { ) }\end{array}$ & $\begin{array}{c}\text { Hasil } \\
\text { Regresi } \\
\text { Cost } \\
\text { (Miliar } \\
\text { Rupiah } \\
\text { ) }\end{array}$ & $\begin{array}{c}\text { Data } \\
\text { Real } \\
\text { Benefit } \\
\text { (Miliar } \\
\text { Rupiah } \\
\text { ) }\end{array}$ & $\begin{array}{c}\text { Data } \\
\text { Real } \\
\text { Cost } \\
\text { (Miliar } \\
\text { Rupiah } \\
\text { ) }\end{array}$ & B/C & B-C \\
\hline 2013 & 14,992 & 12,056 & 17,077 & 12,107 & 1,244 & 2,936 \\
\hline 2014 & 19,787 & 12,876 & 15,979 & 13,352 & 1,537 & 6,911 \\
\hline 2015 & 20,069 & 12,447 & 18,981 & 10,711 & 1,612 & 7,621 \\
\hline 2016 & 15,838 & 10,771 & $\mathbf{2 1 , 0 9 6}$ & $\mathbf{1 2 , 6 1 1}$ & $\mathbf{1 , 4 7 0}$ & $\mathbf{5 , 0 6 7}$ \\
\hline 2017 & 7,093 & 7,846 & 4,645 & 7,217 & 0,904 & $-0,753$ \\
\hline 2018 & $-6,164$ & 3,674 & & & $-1,678$ & $-9,838$ \\
\hline 2019 & $-23,935$ & $-1,747$ & & & 13,698 & $-22,188$ \\
\hline 2020 & $-46,219$ & $-8,417$ & & & 5,491 & $-37,803$ \\
\hline 2021 & $-73,016$ & $-16,334$ & & & 4,470 & $-56,682$ \\
\hline 2022 & 104,32 & $-25,500$ & & & 4,091 & $-78,827$ \\
\hline 2023 & 140,15 & $-35,913$ & & & $-104,237$ \\
\hline
\end{tabular}

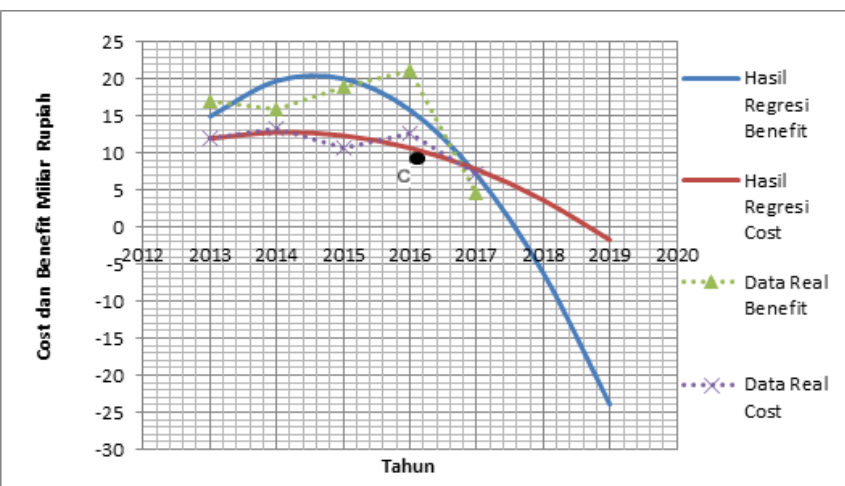

Gambar 3. Grafik hasil regresi data benefit dan cost pada mesin Deutz III

TABEL 15

HASIL AKUMULASI BIAYA BENEFIT PADA MESIN DEUTZ IV

\begin{tabular}{|c|c|c|c|c|c|}
\hline \multirow{2}{*}{ Tahun } & \multicolumn{5}{|c|}{ Deutz IV } \\
\cline { 2 - 6 } & $\mathbf{2 0 1 3}$ & $\mathbf{2 0 1 4}$ & $\mathbf{2 0 1 5}$ & $\mathbf{2 0 1 6}$ & $\mathbf{2 0 1 7}$ \\
\hline Benefit ( Miliar Rupiah) & 18,377 & 11,657 & 18,228 & 15,186 & 5,665 \\
\hline Cost ( Miliar Rupiah) & 13,955 & 9,709 & 12,519 & 8,856 & 8,449 \\
\hline
\end{tabular}

TABEL 16

HASIL REGRESI MESIN DEUTZ IV

\begin{tabular}{|c|c|c|c|c|c|c|}
\hline Tahun & $\begin{array}{c}\text { Hasil } \\
\text { Regresi } \\
\text { Benefit } \\
\text { (Miliar } \\
\text { Rupiah) }\end{array}$ & $\begin{array}{c}\text { Hasil } \\
\text { Regresi } \\
\text { Cost } \\
\text { (Miliar } \\
\text { Rupiah }\end{array}$ & $\begin{array}{c}\text { Data } \\
\text { Real } \\
\text { Benefit } \\
\text { (Miliar } \\
\text { Rupiah } \\
\text { ) }\end{array}$ & $\begin{array}{c}\text { Data } \\
\text { Real } \\
\text { Cost } \\
\text { (Miliar } \\
\text { Rupiah } \\
\text { ) }\end{array}$ & B/C & B-C \\
\hline 2013 & 16,028 & 13,243 & 18,377 & 13,955 & 1,210 & $\begin{array}{c}\text { Miliar } \\
\text { Rupiah } \\
\text { ) }\end{array}$ \\
\hline 2014 & 17,099 & 11,799 & 11,657 & 9,709 & 1,449 & 7,390 \\
\hline 2015 & 15,996 & 10,526 & 18,228 & 12,519 & 1,520 & 3,477 \\
\hline $\mathbf{2 0 1 6}$ & $\mathbf{1 2 , 7 2 0}$ & $\mathbf{9 , 4 2 6}$ & $\mathbf{1 5 , 1 8 6}$ & $\mathbf{8 , 8 5 6}$ & $\mathbf{1 , 3 4 9}$ & $\mathbf{3 , 8 6 4}$ \\
\hline 2017 & 7,270 & 8,498 & 5,665 & 8,449 & 0,855 & $-1,179$ \\
\hline 2018 & $-0,354$ & 7,742 & & & $-0,046$ & $-0,354$ \\
\hline 2019 & $-10,151$ & 7,159 & & & $-1,418$ & $-10,151$ \\
\hline 2020 & $-22,122$ & 6,747 & & & $-3,279$ & $-22,122$ \\
\hline 2021 & $-36,266$ & 6,508 & & & $-5,573$ & $-36,266$ \\
\hline 2022 & $-52,584$ & 6,441 & & & $-8,164$ & $-52,584$ \\
\hline 2023 & $-71,076$ & 6,546 & & & $-10,858$ & $-71,076$ \\
\hline 2024 & $-91,741$ & 6,824 & & & $-13,445$ & $-91,741$ \\
\hline 2025 & $-114,580$ & 7,273 & & & $-15,754$ & $-114,580$ \\
\hline 2026 & $-139,592$ & 7,895 & & & $-17,6811$ & $-139,592$ \\
\hline
\end{tabular}

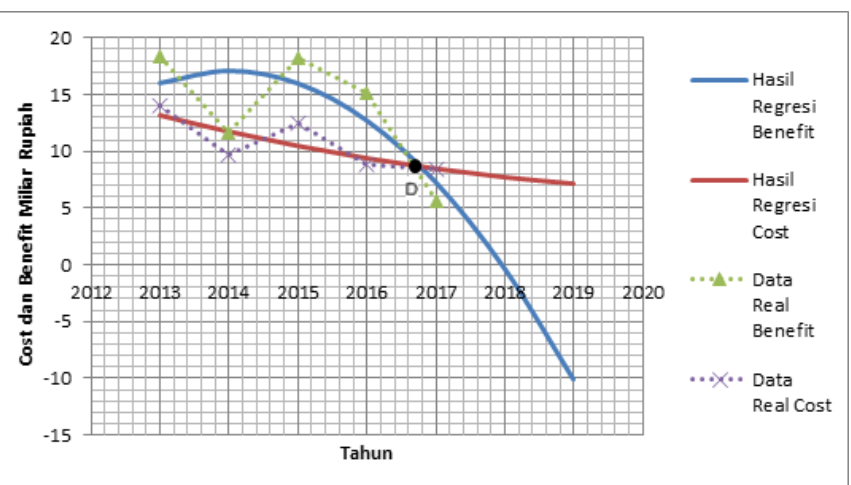

Gambar 4. Grafik hasil regresi data benefit dan cost pada mesin Deutz III

Dari Tabel 10 jika mesin dioperasikan sampai di tahun 2017 maka total kerugian diakhir tahun 2016 sebesar Rp.2,855 Miliar, dan masih mendapat keuntungan di tahun 2016 sebesar Rp. 1,521 miliar.

Berdasarkan Gambar 2 hasil grafik regresi benefit dan cost, perdiksi masa pakai suatu mesin sudah tercapai pada titik pertemuan antara kurva benefit dan kurva cost (A) sudah tidak menguntungkan dan tidak merugikan (breaking point) secara finansial, namun secara teknis masih bisa beroperasi. Operasi yang dilakukan sesudah titik A ini tidak menguntungkan lagi karena kurva cost lebih besar dari kurva benefit, maka pada titik A pertemuan tersebut berada dipertengahan tahun 2016 masa manfaatnya dengan umur mesin 29 tahun ditinjau dari aspek finansial. 


\section{KESIMPULAN DAN SARAN}

A. Kesimpulan

1. Masa pakai keempat unit mesin PLTD Selayar tercapai pada titik pertemuan antara kurva benefit dan kurva cost rata-rata berada pada tahun 2016 dengan masa pakai umur mesin rata-rata 29 tahun ditinjau dari aspek finansial.

2. Berdasarkan grafik hasil regresi benefit dan cost, perediksi masa pakai suatu mesin sudah tercapai pada titik pertemuan antara kurva benefit dan kurva cost(breaking point).

3. Berdasarkan Tabel 15 apabila rasio cost dan benefit lebih besar dari satu maka mesin masih layak operasi, dan apabila rasio benefit dan cost lebih kecil dari satu maka mesin sudah tidak layak operasi, dan apabila rasio benefit dengan cost sama dengan satu maka secara finansial tidak menguntungkan dan juga tidak merugikan (breaking point)

\section{B. Saran}

Untuk mendapatkan hasil yang akurat dalam meregresi nilai benefit dan cost untuk menentukan masa pakai suatu mesin dibutuhkan 10 data benefit dan data cost teratur untuk mendapatkan hasil yang lebih akurat Dari keempat pembangkit tersebut sudah melampaui masa pakainya ditinjau dari aspek finansial, maka perlu diadakan pergantian mesin baru.

\section{REFERENSI}

[1] E. Kreyszig, Matematika Teknik Lanjut buku 2 Edisi ke-2, Gramedia Pustaka, 1993.

[2] M. Syafruddin, L. Hakim, dan D. Despa., "Metode regresi linear untuk prediksi kebutuhan energi listrik jangka panjang (studi kasus Lampung)," Jurnal Informatika dan Teknik Elektro Terapan, vol. 2 no. 2, 2014.

[3] M. Wijana, A. A. A. Triadi, dan L. S. Anwar, "Studi kelayakan penggunaan mesin diesel dengan metode break even point (BEP) dan analisis sensitivitas pada PLTD ," Dinamika Teknik Mesin, vol. 6 no. $1,2016$.

[4] M. Abeulla, Solar Power Probalistik Forecasting by Using Multiple Linear Regression Analysis, IEEE Press, 2015.

[5] J. Liu, "Fault Prediction For Power Plant Equipment Based On Support Vector Regresssion" Tianjin University, 2015.

[6] M. Rahmati, "Thermal Performance of Natural Draft Wet Cooling Towers Under Cross-Wind Conditionsn Based On Experimental Data And Regression Analysis". IEEE Press. 2016.

[7] PT. PLN (Persero) Pembangkitan Tello Unit PLTD Selayar. Laporan Penguasahaan Unit PLTD Selayar 2013-2017, Selayar, 2017. 